\title{
THE PERFORMANCE MEASURMENT SYSTEM KEY INDICATORS AND THE DETERMINANTS IMPACT ON THE LEVEL OF DECENTRALIZATION USING AS AN EXAMPLE A SUBDIVISIONAL UNIT FROM THE BULGARIAN SOCIAL HEALTH AND CARE EXPERIENCE
}

\author{
Venelin Terziev ${ }^{1}$ and Stoyanka Petkova - Georgieva ${ }^{2}$ \\ ${ }^{1}$ Academician of the Russian Academy of Natural History, Moscow, Russia, \\ Prof. D.Sc. (Ec.), D.Sc. (National Security), D.Sc. (Social Activities), Ph.D., National Military \\ University, Veliko Tarnovo, Bulgaria; University of Rousse, Rousse, Bulgaria, terziev@skmat.com \\ ${ }^{2} \mathrm{PhD}$, Associate Professor, University „Prof. d-r Assen Zlatarov” - Bourgas, Bulgaria, \\ s.p.petkova@gmail.com
}

\begin{abstract}
There is investigated the influence of the determinants - subunit interdependences and knowledge transfer costs, on the level of decentralization and the performance measurement system (PMSs) using as an example a subdivisional unit from the Bulgarian social health and care experience. There is suggested a model of three equations about according to the impact of the above factors. There is carried out an empirical investigation and the summarized statistics for researched variables and some statistical interdependences are reviewed.
\end{abstract}

Keywords: performance measurement system, level of decentralization, impact, healthcare subdivisional unit.

\section{INTRODUCTION}

The system of performance measures is a significant and most common instrument for increasing the management efficiency of an organization, using as an example a Bulgarian health and care subdivisional unit (an example of a public hospital). In the contemporary literature a lot of new versions of systems of performance measures have been suggested which can be classified to balanced and focused. The balanced scorecard is the usual representative in the first group and the system of selective performance measures is the representative of the second (Petkova - Georgieva, 2016; Abernethy, Lillis, 1995).

A significant problem for organizations with multidivisional structures (such as are the Bulgarian subdivisional healthcare units) is establishing of the optimal decentralization in manager's decision-making. The level of decentralization influences the structure and design of performance measurement system (PMS). Therefore, the improvement of PMS in organizations with multidivisional structure demands to be established the factors, which mostly influence the level of decentralization and the structure of PMS.

This study has on an object to assess the impact of the two factors - subunit interdependencies and 
knowledge transfer costs both on decentralization and on structure of PMS. For this reason, there have been experienced some predictions with a simultaneous equation model that captures the level of decentralization and the structure of PMS.

In the present investigation is focused on the submition of considering the second stage of the conducted research. The study is based on the analytical frameworks developed by Jensen and Meckling (Jensen, Meckling, 1992) and Milgrom and Roberts (Milgrom, Roberts, 1995b). The model assesses choices relating to level of decentralization and two forms of subunit performance metrics, namely, aggregated performance measures (eg. profit or ROI) and disaggregated performance measures or what we refer to as specific performance measures (e.g. production expenditure, $R \& D$, sales revenues). The simultaneous equation model can be summarized as follows:

- $\quad D E C E N=f(A G G, S P E C, S I, K T C)$

- $A G G=f(D E C E N, S P E C, S I, K T C)$

- $S P E C=f(D E C E N, A G G, S I, K T C)$

- DECEN - Decentralization

- AGG - Aggregated PMs

- SPEC - Specific PMs

- $\mathrm{SI}$ - Subunit Interdependencies

- KTC - Knowledge Transfer Cost

The theoretical study as certain the fact that the decisions relating to decentralization and PMS choices are made simultaneously and that these choices are influenced by a number of exogenous factors. According to this the impact of interdependencies among subunits (as it is in the Bulgarian healthcare practice) and cost of transferring knowledge on these choices is discussed (Fama, French, 1993a).

The variable knowledge transfer costs have two dimensions: one capturing specific knowledge (i.e. knowledge impacted at the subunit level) and second capturing environmental factors (i.e. competition, strategy, size, growth). Respectively there are used three variables to capture the knowledge transfer costs associated with environmental factors: growth opportunities, competition and size (Fama, French, 1993a).

The impact of the mentioned above factors on the level of decentralization and the structure of performance measurement system are summarized in the following hypotheses:

- H1: The level of decentralization decreases as the subunit operating interdependencies increase and increases as the level of subunit specific knowledge, subunit growth opportunities, size and competition increase.

- H2: The use of aggregated subunit performance measures decreases when subunit interdependencies increase and increases when competition intensifies.

- H3: The use of specific subunit performance measures decreases as subunit interdependencies increase and increases as subunit specific knowledge increases and competition intensifies (Fama, French, 1993a).

\section{METHODOLOGY OF INVESTIGATION}

We conducted our research in a health care subdivisional unit (the real name of the health care organization is confident). The necessary data for the test of the model was obtained from a survey of 78 managers (doctors and administrators with skills in health care management and hired at a hospital management positions) from 18 divisions of the experienced subdivisional units (a public hospital).

At the first stage of the conducted research by means of checklists there have been gathered some information about the following variables:

- DECEN - summary statistics for decentralization;

- AGG - use of own-level aggregated performance measures;

- SPEC - use of specific measures;

- SK - specific knowledge;

- SUPPLY - operating interdependencies; 
- GROWTH - growth opportunities;

- SIZE - size of the unit;

- PPERF - past performance;

- IMPACT1- impact of unit on performance of other units in firm;

- IMPACT2 - impact of other units in firm on performance of own unit;

- RSIZE - relative size of unit in firm;

- COMP - degree of competition;

- INT_AGG - intensity of own-level aggregated measures;

- INT_SPEC - intensity of specific measures;

- CPERF - experience and current performance.

Also, the summarized statistics are calculated for each variable: Mean, Standard Deviation, Median, Minimum, Maximum.

Endogenous variables. Level of decentralization

The level of decentralization describes the degree to which decision rights are assigned to lower level managers. The managers were asked to indicate their influence over a range of decisions (e.g. strategic, human resource management, operational, investment and marketing decisions). The measure (DECEN) was obtained by averaging the responses to five survey items. Factor analysis and reliability assessment of the five items supported this approach (Table 1).

Aggregated measures (AGG) such as profit or ROI summarize subunit performance in one measure. The respondents had to to assign weights to the relative importance of AGG measures in comparison with other performance metrics.

The specific measure variable (SPEC) summed the weights on the two items that capture the use of measures that inform on specific functions (e.g. expenditure and revenue data relating to R\&D, marketing, etc.) within the business unit.

\section{Exogenous variables. Interdependencies}

To test the relative importance of the two-performance metrics (AGG, SPEC) interdependences between subunits by means of two questions were measured. The first item asked respondents to identify the extent to which their activities impacted other subunits (IMPACT1), and the second item asked the extent to which their performance was affected by the activities carried out by other subunits (IMPACT2) (Milgrom, Roberts, 1995b).

To test the impact of interdependencies on decentralization (DECEN) we used a measure that focuses on the exchange of goods and services between subunits within the firm.

Two questions had been asked to the subunit managers:

- The percentage of incoming supply of goods or service sourced from other subunits in percentage of the total incoming supply of goods, and

- The percentage of total outgoing goods provided to other subunits.

The variable SUPPLY is the sum of these two percentages.

Knowledge Transfer Costs

There are two dimentions that describe the variable Knowledge Transfer Costs: one capturing specific knowledge (i.e. knowledge impacted at the subunit level) and a second capturing environmental factors (i.e. competition, strategy, size, growth).

\section{Specific knowledge}

The managers were asked to rate their knowledge relative to their superior's in their area of responsibility uing the six-item scale (Ittner, Larcker, 2000). The results of the factor analysis indicated that there was only one common factor (Table 1). A measure for specific knowledge (SK) is resulted as a sum of the scores on the six items. 


\section{Environmental condition}

There are presented three environmental elements according to the conditions in which the firm operates, namely, growth opportunities (GROWTH), size (SIZE) and competition (COMP).

To measure growth opportunities managers were asked to rate growth expectations for their own subunit and for the industry in which the subunit operates. The two-item measure allowed for a validation test between the items. The scale reliability has been evaluated with Cronbach's alpha. The estimated coefficient was 0.74 , which is beyond conventional levels. The variable size is defined as the number of employers working in a unit.

The competition is measured using instrument that comprises different elements of competition, namely, price, promotion and distribution, product quality, and product variety. There was tested whether the construct (COMP) instrument was unidimensional using factor analysis. The results indicate that the four items represent one construct (Table 1). The alpha reliability of the four items $(0.64)$ also supported the use of a summed measure.

\section{Control Variables}

As a result of the scientific literature there were included in the model three control variables as followes:

- The subunit performance (Jeong, Maddala, 1993b);

- The relative size as a proxy for subunit risk differences (Nagar, 1999);

- The intensity of the performance measures as an indicator for the sensitivity and precision of the measure (Jensen, Meckling, 1992).

The inclusion of these variables minimizes the possibility of omitted variable bias. In order to to be identified our model it is used two separate measures for variable subunit performance, namely past performance (PPERF) and current performance (CPERF). The two constructs are highly correlated supporting the validity of our approach. The performance is measured by asking managers to rate how their subunit performs relatively to competitors, and relatively to what is expected by their superiors. The scale reliability is assessed with Cronbach's alpha. Coefficient estimates are 0.58 for CPERF and 0.68 for PPERF.

Table 1. Results of principal factor and maximum likelihood factor analysis of responses of managers to survey questions

\begin{tabular}{|c|c|c|}
\hline Variable & Factor loading & Communality Estimate (h ) \\
\hline \multirow[t]{3}{*}{ SK } & \multicolumn{2}{|c|}{ Cronbach's alpha $=0.86$} \\
\hline & \multirow{2}{*}{\multicolumn{2}{|c|}{$\begin{array}{l}\text { Maximum likelihood solution tests: } \mathrm{H} 1 \text { ( } 1 \text { common factor) versus } \mathrm{H} 0 \text { (no common } \\
\text { factors), } x^{2}=202.056, p=0.00 \\
H 1 \text { (> } 1 \text { common factor) versus } \mathrm{H} 0 \text { (1 common factor), } x^{2}=27.440, p=0.00\end{array}$}} \\
\hline & & \\
\hline SK1 & 75 & 0.556 \\
\hline SK2 & 72 & 0.524 \\
\hline SK3 & 69 & 0.473 \\
\hline SK4 & 70 & 0.488 \\
\hline SK5 & 62 & 0.381 \\
\hline SK6 & 79 & 0.632 \\
\hline \multirow[t]{2}{*}{ DECEN } & \multicolumn{2}{|c|}{ Cronbach's alpha $=0.73$} \\
\hline & \multicolumn{2}{|c|}{$\begin{array}{c}\text { Maximum likelihood solution tests: } \mathrm{H} 1 \text { (1 common factor) versus } \mathrm{H} 0 \text { (no common } \\
\text { factors), } x^{2}=71.87, p=0.00\end{array}$} \\
\hline
\end{tabular}


IJASOS- International E-Journal of Advances in Social Sciences, Vol. V, Issue 14, August 2019

\begin{tabular}{|c|c|c|}
\hline & \multicolumn{2}{|c|}{$\mathrm{H} 1$ ( $>1$ common factor) versus $\mathrm{H} 0$ (1 common factor), $\mathrm{x}^{2}=1.716, \mathrm{p}=0.89$} \\
\hline DECEN1 & 57 & 0.324 \\
\hline DECEN2 & 49 & 0.243 \\
\hline DECEN3 & 62 & 0.379 \\
\hline DECEN4 & 69 & 0.479 \\
\hline DECEN5 & 55 & 0.303 \\
\hline COMP & \multicolumn{2}{|c|}{$\begin{array}{l}\text { Cronbach's alpha }=0.64 \\
\begin{array}{l}\text { Maximum likelihood solution tests: } \mathrm{H} 1 \text { ( } 1 \text { common factor) versus } \mathrm{H} 0 \text { (no common } \\
\text { factors), } \mathrm{X}^{2}=43.39, \mathrm{p}=0.00\end{array} \\
\mathrm{H} 1 \text { (> } 1 \text { common factor) versus } \mathrm{H} 0 \text { ( } 1 \text { common factor), } \mathrm{x}^{2}=4.719, \mathrm{p}=0.09\end{array}$} \\
\hline COMP1 & 43 & 0.185 \\
\hline COMP2 & 50 & 0.255 \\
\hline COMP3 & 58 & 0.335 \\
\hline COMP4 & 64 & 0.416 \\
\hline GROWTH & & \\
\hline PPERF & & \\
\hline CPERF & & \\
\hline
\end{tabular}

Relative size was measured as the percentage of sales of the subunit to the total firm or the total of the assets as a percentage to total firm assets.

Intensity of the performance measure was captured by asking respondents how well the two performance measures captured the subunit's effort (intensity of own level aggregated measures - INT_AGG; intensity of specific measures - INT_SPEC).

Results of practical investigation. Correlation analysis

Pearson's correlation coefficients among all the variables are presented in Table 2. It appears that decentralization is related to interdependencies (SUPPLY and IMPACT2), specific knowledge (SK), growth opportunities (GROWTH), and SIZE in the way that was predicted. Decentralization is also positively associated with the use of aggregated measures and negatively associated with specific measures.

Consistent with the expectation a negative relation between use of aggregated performance measures (AGG) and interdependencies (IMPACT1) was founded. The results relating to the specific performance measure variable (SPEC) do not support the expectations. There appears to be no correlation between interdependencies and SPEC and a negative relation between SPEC and specific knowledge. There appears to be no relation between the three choice variables and level of competition (COMP). 
Test of the Model

There were used three simultaneous equations to test the presented model. The composed equations capture:

- The degree of decentralization (1);

- The use of aggregated performance measures (2);

- The use of specific performance measures (3).

These equations are expressed as follows:

DECEN $_{i}=\alpha_{0}+\alpha_{1}$ AGG $_{i}+\alpha_{2}$ SPEC $_{i}+\alpha_{3}$ SK $_{i}+\alpha_{4}$ SUPPLY $_{i}+\alpha_{5}$ GROWTH $_{i}+\alpha_{6}$ SIZE $_{i}+\alpha_{7}$ PPERF $_{i}+$ $\alpha_{8} C_{C O M P}+\varepsilon_{i}{ }^{D E C E N}$

$A G G_{i}=\beta_{0}+\beta_{1}$ DECEN $_{i}+\beta_{2}$ SPEC $_{i}+\beta_{3}$ SK $_{i}+\beta_{4}$ IMPACT $_{i}+\beta_{5}$ IMPACTi $+\beta_{6}$ RSIZE $_{i}+\beta_{7}$ INT_AGG $_{i}+\beta_{8}$ COMP $_{i}$ $+\varepsilon_{i}^{A G G}$

SPEC $_{i}=\gamma_{0}+\gamma_{1}$ DECEN $_{i}+\gamma_{2}$ AGG $_{i}+\gamma_{3}$ SK $_{i}+\gamma_{4}$ IMPACT $_{i}+\gamma_{5}$ IMPAKT2 $_{i}+\gamma_{6}$ COMP $_{i}+\gamma_{7}$ CPERF $_{i}+\gamma_{8}$ INT_SPEC $_{i}$ $+\gamma_{9} R S I Z E_{i}+\varepsilon_{i}$ SPEC

Table 2. Pearson's correlation coefficients among all the variables

\begin{tabular}{|c|c|c|c|c|c|c|c|c|c|c|c|c|c|c|c|}
\hline & 1 & 2 & 3 & 4 & 5 & 6 & 7 & 8 & 9 & 10 & 11 & 12 & 13 & 14 & 15 \\
\hline 1 & 1 & & & & & & & & & & & & & & \\
\hline 2 & $\begin{array}{l}-0.13 \\
(0.27)\end{array}$ & 1 & & & & & & & & & & & & & \\
\hline 3 & $\begin{array}{c}0.30 \\
(0.01)\end{array}$ & $\begin{array}{c}-0.44 \\
(0.00)\end{array}$ & 1 & & & & & & & & & & & & \\
\hline 4 & $\begin{array}{c}0.14 \\
(0.22)\end{array}$ & $\begin{array}{l}-0.19 \\
(0.08)\end{array}$ & $\begin{array}{c}0.57 \\
(0.00)\end{array}$ & 1 & & & & & & & & & & & \\
\hline 5 & $\begin{array}{l}-0.13 \\
(0.26)\end{array}$ & $\begin{array}{c}0.02 \\
(0.83)\end{array}$ & $\begin{array}{l}-0.22 \\
(0.06)\end{array}$ & $\begin{array}{l}0.08 \\
(0.46)\end{array}$ & 1 & & & & & & & & & & \\
\hline 6 & $\begin{array}{l}-0.27 \\
(0.02)\end{array}$ & $\begin{array}{c}0.06 \\
(0.62)\end{array}$ & $\begin{array}{l}-0.15 \\
(0.18)\end{array}$ & $\begin{array}{l}-0.02 \\
(0.84)\end{array}$ & $\begin{array}{l}0.51 \\
(0.00)\end{array}$ & 1 & & & & & & & & & \\
\hline 7 & $\begin{array}{c}-0.11 \\
(0.34)\end{array}$ & $\begin{array}{c}0.01 \\
(0.91) \\
\end{array}$ & $\begin{array}{l}-0.26 \\
(0.02)\end{array}$ & $\begin{array}{l}-0.07 \\
(0.55)\end{array}$ & $\begin{array}{l}0.56 \\
(0.00)\end{array}$ & $\begin{array}{l}0.66 \\
0.00 \\
\end{array}$ & 1 & & & & & & & & \\
\hline 8 & $\begin{array}{c}0.07 \\
(0.57) \\
\end{array}$ & $\begin{array}{l}-0.35 \\
(0.00)\end{array}$ & $\begin{array}{c}0.41 \\
(0.00)\end{array}$ & $\begin{array}{c}0.13 \\
(0.26) \\
\end{array}$ & $\begin{array}{l}-0.12 \\
(0.30)\end{array}$ & $\begin{array}{l}0.06 \\
0.61 \\
\end{array}$ & $\begin{array}{c}0.10 \\
(0.41)\end{array}$ & 1 & & & & & & & \\
\hline 9 & $\begin{array}{l}-0.07 \\
(0.53)\end{array}$ & $\begin{array}{l}-0.31 \\
(0.01)\end{array}$ & $\begin{array}{l}0.36 \\
(0.00)\end{array}$ & $\begin{array}{l}0.56 \\
(0.00)\end{array}$ & $\begin{array}{c}-0.08 \\
(0.48)\end{array}$ & $\begin{array}{l}-0.05 \\
0.65\end{array}$ & $\begin{array}{c}-0.16 \\
(0.15)\end{array}$ & $\begin{array}{c}0.05 \\
(0.64)\end{array}$ & 1 & & & & & & \\
\hline 10 & $\begin{array}{c}0.10 \\
(0.37)\end{array}$ & $\begin{array}{l}-0.38 \\
(0.00)\end{array}$ & $\begin{array}{c}0.29 \\
(0.01)\end{array}$ & $\begin{array}{c}0.05 \\
(0.68)\end{array}$ & $\begin{array}{c}-0.14 \\
(0.24)\end{array}$ & $\begin{array}{l}-0.01 \\
(0.93\end{array}$ & $\begin{array}{c}-0.14 \\
(0.21)\end{array}$ & $\begin{array}{c}0.02 \\
(0.83)\end{array}$ & $\begin{array}{c}0.05 \\
(0.64)\end{array}$ & 1 & & & & & \\
\hline 11 & $\begin{array}{l}-0.28 \\
(0.01)\end{array}$ & $\begin{array}{c}0.12 \\
(0.29) \\
\end{array}$ & $\begin{array}{l}-0.17 \\
(0.13)\end{array}$ & $\begin{array}{c}-0.11 \\
(0.34)\end{array}$ & $\begin{array}{l}0.16 \\
(0.17)\end{array}$ & $\begin{array}{r}0.45 \\
(0.00 \\
\end{array}$ & $\begin{array}{l}0.40 \\
(0.00)\end{array}$ & $\begin{array}{l}-0.08 \\
(0.48)\end{array}$ & $\begin{array}{l}-0.12 \\
(0.30)\end{array}$ & $\begin{array}{l}0.06 \\
0.61\end{array}$ & 1 & & & & \\
\hline 12 & $\begin{array}{c}0.18 \\
(0.11)\end{array}$ & $\begin{array}{l}-0.15 \\
(0.20)\end{array}$ & $\begin{array}{c}0.19 \\
(0.09)\end{array}$ & $\begin{array}{l}0.43 \\
(0.00)\end{array}$ & $\begin{array}{l}0.11 \\
(0.33)\end{array}$ & $\begin{array}{l}-0.20 \\
(0.07\end{array}$ & $\begin{array}{l}-0.27 \\
(0.02)\end{array}$ & $\begin{array}{c}-0.10 \\
(0.38)\end{array}$ & $\begin{array}{c}0.52 \\
(0.00)\end{array}$ & $\begin{array}{c}0.02 \\
(0.90)\end{array}$ & $\begin{array}{c}-0.12 \\
(0.31)\end{array}$ & 1 & & & \\
\hline 13 & $\begin{array}{c}0.28 \\
(0.01)\end{array}$ & $\begin{array}{c}-0.01 \\
(0.96)\end{array}$ & $\begin{array}{c}0.01 \\
(0.96)\end{array}$ & $\begin{array}{c}0.04 \\
(0.72)\end{array}$ & $\begin{array}{l}-0.07 \\
(0.50)\end{array}$ & $\begin{array}{l}-0.18 \\
(0.10\end{array}$ & $\begin{array}{c}-0.28 \\
(0.01)\end{array}$ & $\begin{array}{c}-0.20 \\
(0.08)\end{array}$ & $\begin{array}{l}0.04 \\
(0.70)\end{array}$ & $\begin{array}{c}-0.01 \\
0.95\end{array}$ & $\begin{array}{c}-0.18 \\
(0.11)\end{array}$ & $\begin{array}{c}0.12 \\
0.31)\end{array}$ & 1 & & \\
\hline 14 & $\begin{array}{l}-0.15 \\
(0.18)\end{array}$ & $\begin{array}{c}0.03 \\
(0.78)\end{array}$ & $\begin{array}{c}0.12 \\
(0.30)\end{array}$ & $\begin{array}{l}-0.02 \\
(0.83)\end{array}$ & $\begin{array}{c}0.04 \\
(0.76)\end{array}$ & $\begin{array}{l}0.08 \\
0.50\end{array}$ & $\begin{array}{c}0.05 \\
0.69\end{array}$ & $\begin{array}{c}0.19 \\
0.10\end{array}$ & $\begin{array}{l}0.07 \\
0.52\end{array}$ & $\begin{array}{l}0.02 \\
0.87\end{array}$ & $\begin{array}{l}-0.07 \\
(0.50)\end{array}$ & $\begin{array}{c}0.03 \\
(0.79)\end{array}$ & $\begin{array}{c}-0.71 \\
(0.00)\end{array}$ & 1 & \\
\hline 15 & $\begin{array}{c}0.04 \\
(0.73)\end{array}$ & $\begin{array}{l}-0.06 \\
(0.59)\end{array}$ & $\begin{array}{c}0.10 \\
(0.39)\end{array}$ & $\begin{array}{l}0.13 \\
(0.25)\end{array}$ & $\begin{array}{c}0.00 \\
0.99)\end{array}$ & $\begin{array}{l}0.09 \\
0.41\end{array}$ & $\begin{array}{l}0.17 \\
0.13)\end{array}$ & $\begin{array}{l}0.06 \\
(0.60)\end{array}$ & $\begin{array}{c}-0.03 \\
(0.78)\end{array}$ & $\begin{array}{c}0.37 \\
(0.00)\end{array}$ & $\begin{array}{c}0.07 \\
(0.52)\end{array}$ & $\begin{array}{l}-0.07 \\
(0.53)\end{array}$ & $\begin{array}{c}0.11 \\
(0.34)\end{array}$ & $\begin{array}{c}-0.06 \\
(0.63)\end{array}$ & 1 \\
\hline
\end{tabular}

Legend: 1 - AGG - use of own-level aggregated performance measures; 2 - SPEC - use of specific measures; 3 - DECEN - summary statistics for decentralization; 4 - SK - specific knowledge; 5 - SUPPLY operating interdependencies; 6 - IMPACT 1- impact of unit on performance of other units in firm; 7 IMPACT 2 - impact of other units in firm on performance of own unit; 8 - GROWTH - growth opportunities; 9 CPERF - experience and current performance; 10 - SIZE - size of the unit; 11 - RSIZE - relative size of unit in firm; 12 - PPERF - past performance; 13 - INT_AGG - intensity of own-level aggregated measures; 14 INT_SPEC - intensity of specific measures; 15 - COMP - degree of competition. 
DECEN, AGG and SPEC are the jointly determined endogenous variables. There were therefore used all three composed equations to describe adequately the observed values. The complication in estimating this system is that ordinary least squares is inconsistent when the disturbances are correlated with the explanatory variables. To solve this problem "instrumental" variables that are uncorrelated by assumption with the disturbances were used. Two-stage-least squares (2SLS) method is a legitimate instrumental variable estimator and it is used to estimate the system. Monte Carlo studies have shown 2SLS to have small-sample properties superior on most criteria to all other estimators.

In this connection a bootstrapping method within the simultaneous equation framework was used. The main advantage of the bootstrapping approach is preserving any relation in the original data between instruments and disturbances while resampling (Kothari, Shanken, Sloan, 1995c).

The main reason to use 2SLS was the endogeneity of the performance measuring system and organizational design variables. The test was based on the following procedure:

- Estimating the model by 2SLS and computing the estimated residual and the predicted instruments for each equation.

- Resampling the data for the original instrument, the estimated residual and the predicted instruments.

- Using the original instruments and the estimated residual to compute a value for the dependent variable.

- Computing the bootstrap estimates of the parameters by using the computed value of the dependent variable, the predicted instruments and the original instruments.

The estimation results based on the bootstrapping approach with 2000 replications are presented in Table 3. The empirical distribution of the parameter estimates is used to bootstrap confidence intervals.

The F-statistics show that the three equations are significant at the all three-significance level. The adjusted $\mathrm{R} 2$ for the decentralization regression is $43.39 \%$ providing strong support for the explanatory ability of the independent variables. As expected, top management are likely to assign more decision rights to subunits where managers have a high level of specific knowledge (coefficient $=0.10$, $p$-value $<0.01$ ). This finding is consistent with the idea that specific knowledge at the local level increases the efficiency of decentralized decision making compared to a centralized decision-making structure.

Table 3. Two stage least squares estimation results based on the bootstrapping approach

\begin{tabular}{|c|c|c|c|c|c|c|}
\hline & P.S. & DECEN & P.S. & AGG & P.S. & SPEC \\
\hline Constant & & $-1.9587(2.3196)$ & & $11.4750(51.9683)$ & & $125.298(41.4135) / 10 \% /$ \\
\hline AGG_P & + & $0.0029(0.0070)$ & & & $?$ & $-0.3050(0.4126)$ \\
\hline SPEC_P & & $0.0131(0.0172)$ & $?$ & $0.0866(0.3937)$ & & \\
\hline DECEN_P & & & + & $10.0131(9.8159)$ & $?$ & $-17.9278(7.9784) / 10 \% /$ \\
\hline SK & + & $\begin{array}{c}0.0989(0.0196) \\
/ 10 \% /\end{array}$ & - & $-0.4391(1.0128)$ & + & $2.0889(1.0153) / 5 \% /$ \\
\hline SUPPLY & - & $-0.0056(0.0031)$ & & & & \\
\hline GROWTH & + & $0.2768(0.1081) / 5 \% /$ & & & & \\
\hline SIZE & + & $0.1674(0.0760) / 5 \% /$ & & & & \\
\hline PPERF & + & $0.0142(0.0429)$ & & & & \\
\hline IMPACT1 & & & - & $-4.0025(2.624)$ & - & $-0.2080(3.1169)$ \\
\hline
\end{tabular}


IJASOS- International E-Journal of Advances in Social Sciences, Vol. V, Issue 14, August 2019

\begin{tabular}{|c|c|c|c|c|c|c|}
\hline IMPACT2 & & & - & $5.2051(2.916) / 1 \% /$ & - & $-3.3440(3.1938)$ \\
\hline RSIZE & & & + & $-0.1838(0.1837)$ & + & $0.0154(0.2337)$ \\
\hline INT_AGG & & & + & $0.2693(0.1690)$ & & \\
\hline COMP & + & $-0.0348(0.0246)$ & + & $-0.5142(0.8407)$ & + & $-0.2542(0.8424)$ \\
\hline CPERF & & & & & - & $-4.1123(2.2918) / 1 \% /$ \\
\hline INT_SPEC & & & & & + & $0.0955(0.2208)$ \\
\hline ADJ. R & & $43.39 \%$ & & $12.76 \%$ & & $11.96 \%$ \\
\hline F-statistic & & 6.366 & & 2.024 & & 1.871 \\
\hline Prob(F) & & 0.0001 & & 0.0397 & & 0.0548 \\
\hline
\end{tabular}

Legend: The standard errors are presented in parenthesis. The significance is based on the empirical distribution of the parameter estimates. $/ 10 \% /, / 5 \% /$ and $/ 1 \% /$ denotes significance levels. $P$ denotes predicted values from first stage regression.

There were founded some evidences that the environmental conditions which represent dimensions of knowledge transfer costs were significant in explaining the extent to which decision rights are delegated. Both growth opportunities (GROWTH) and SIZE are positively related to decentralization (coefficient $=0.28$, and 0.17 respectively, both $p$-value $<0.05$ ). Also there were found some proofes for the prediction relating to interdependencies and decentralization. There was argued that interdependencies between subunits raise the coordination cost of decentralization. Local managers are more likely to make locally-optimal decision, ignoring the impact of their decisions on other units. To ensure globally-optimal results, higher manager may be forced to retain certain decision rights. There was founded that interdependencies between subunits (SUPPLY) are negatively correlated with the level of decentralization in a firm (coefficient $=-0.01, p$-value $<0.05$ ). It was surprising to find no evidence that decentralization choice and PMS design are associated. Both AGG_P and SPEC_P are insignificant.

The adjusted R2 for the equation relating to the use of aggregate performance measures (Equation 2) indicated that the model has some explanatory ability (i.e. $12.76 \%$ ). The expectations were only partially supported. An unexpected and significantly positive relation between the impact of other subunits on the performance of the subunit (coefficient $=5.21, p$-value $<0.10$ ) and the use of aggregated own level performance measures was founded. This finding is counter-intuitive and at first appears contrary to the notion of informativeness. However, given the top management are aware of the interdependencies existing among subunits, the use of aggregate profit measures has information content about how well a manager is anticipating the effects of other subunit activities on their own activities. There were no significant relations with the other two endogenous variables (DECEN_P and SPEC_P).

The specific measure regression, Equation 3, also provides some explanatory power with $11 \%$ of the variance explained. As predicted, specific knowledge is associated with use of specific measures (coefficient $=2.09$, p-value $<0.05$ ). Top management use of specific measures increases with greater level of specific knowledge, which suggests positive payoffs to using these measures. There is, however, no association between interdependencies and the use of specific measures. The significant association between choice of organization design and the use of specific measures is a core result of the paper.

\section{CONCLUSION}

Our findings partly support the expectations in relation to the determinants of organizational design. Strong evidence for the importance of knowledge transfer costs in determining choices relating to decentralization and the use of specific performance measures was founded. There was also found out that interdependency between subunits influence the extent to which top management delegate decision rights and their use of aggregated performance measures. What is of particular interest is that the type of interdependencies influences the use of aggregate measures. The results do not confirm prior literature that top management will be reluctant to use aggregated subunit measures in the presence of interdependencies (Dunk, 1993; Milgrom, Roberts, 1995b). It would appear that if a subunit's activities are influenced by the actions of 
managers in other units, aggregated measures are used to a greater extent. There was found some proof for there is a sequence in choices relating to structure and PMS design (Sotirov, Sakakushev, Koriykov, Georgiev, Zhel, Popesku, 2010a).

However, the gained results are similar to the results in the literature (Bushman, Indjejikian, Smith, 1995a; Petkova, Tasheva, Petkov, 2010). There was demonstrated that the relation between organization structural decisions and performance measure choice is likely to be unidirectional.

There are a number of caveats that should be recognized when considering the evidence presented in this paper.

First, is the simplicity of the model, while there have been extended prior research and was examined only two dimensions of organizational design. There are numerous other elements of organizational design.

Second, is the potential for measurement error. Survey data are only able to capture the perceptions of respondents and thus may be subject to bias.

Third, is the potential for omitted variable bias and while it is controlling for a number of variables likely to influence this bias there is no doubt others.

\section{REFERENCE LIST}

Petkova - Georgieva, St., (2016). Nasoki za usavarshenstvane strukturiraneto na deynostite po zdraveopazvane, Akademichno spisanie „Upravlenie i obrazovanie”, volume II, str. 122-128, International Scientific Conference "Management and Education”, Burgas, Bulgaria, 23-24 Yuni, 2016 (Петкова - Георгиева, Ст., Насоки за усъвършенстване структурирането на дейностите по здравеопазване, Академично списание „Управление и образование”, volume II, стр. 122-128, International Scientific Conference "Management and Education”, Burgas, Bulgaria, 23-24 Юни, 2016).

Abernethy, M.A., Lillis, A.M., (1995). The Impact of Manufacturing Flexibility on Management Control System Design, Accounting, Organizations and Society, 20(4), 1995

Bushman, R.M., Indjejikian, R.J., Smith, A., (1995a). Aggregate Performance Measures in Business Unit Manager Compensation: The Role of Intra Firm Interdependencies, Journal of Accounting Research (33 Supplement), 1995.

Dunk, A.S., (1993). The Effect of Budget Emphasis and Information Asymmetry on the Relation Between Budgetary Participation and Slack, The Accounting Review 68(2), 1993.

Fama, E.F., French, K.R., (1993a). Common Risk Factors in Returns on Stocks and Bonds, Journal of Financial Economics, 33, 1993

Ittner, C.D., Larcker, D.F., (2000). Assesing Empirical Research in Managerial Accounting: a Value Based Perspective, Journal of Accounting and Economics, 4, 2000.

Jensen, M.C., Meckling, W.H., (1992). Specific and General Knowledge and Organizational Structure, in: Werin, L. and Wijkander, H. (Eds.) Contract Economics, Blackwell Publishers, Cambridge, 1992.

Jeong, J., Maddala, G.S. (1993b), A Perspective on Application of Bootstrap Methods in Econometrics, In: Maddala, G.S., Rao, C.R., Vinod, H.D. (eds.) Handbook of Statistics, vol. 11, Elsevier Science: Amsterdam, 1993.

Keating, A.S., (1997). Determinants of Divisional Performance Evaluation Practices, Journal of Accounting and Economics, 24, 1997.

Milgrom, P., Roberts, J., (1995b). Complementarities and Fit: Strategy, Structure and Organizational Change in Manufacturing, Journal of Accounting and Economics, 19, 1995.

Nagar, V., (1999). Organizational Design Choices in Retail Banking, Working-paper, University of Michigan Business School, 1999.

Petkova - Georgieva, St., (2017). The Importance of the Conceptual Controlling Model in the Health and Care Management System Using as an Example the Management of a Hospital, annual of "Prof. Dr. 
Assen Zlatarov", стр. 109 - 114, v. XLVI, book 2, Burgas, Bulgaria, 2017.

Petkova, St., Y. Tasheva, P. Petkov, (2010). Tendencies in the scope and structure of the controlling processes related to the use motor fuels, Oxidation Communications, book 3, vol. 33, p.612-619, ISSN 0209-4541, 2010.

Sotirov, B., Sakakushev, B., Koriykov, Ts., Georgiev, Ts, Zhel, Zh. F, Popesku, G. (2010a). „Menidzhmant na kachestvoto i metrologiya" - spetsialnost ot evropeyskoto obrazovatelno prostranstvo. // Standartizatsiya, Metrologiya, Sertifikatsiya, 2010, broy I, str. 25-28, ISSN 1310-0831 (Сотиров, Б., Сакакушев, Б., Корийков, Ц., Георгиев, Ц, Жел, Ж. Ф, Попеску, Г. „Мениджмънт на качеството и метрология" - специалност от европейското образователно пространство. // Стандартизация, Метрология, Сертификация, 2010, брой I, стр. 25-28, ISSN 1310-0831).

Kothari, S.P., Shanken, J., Sloan, R.G., (1995c). Another Look at the Cross-section of Expected Stock Returns, Journal of Finance (50)1, 1995. 